ISA

\title{
Investigation of the Potential for Bark Patch Grafting to Facilitate Tree Wound Closure in Arboricultural Management Practice
}

\author{
G.M. Moore and P.G. McGarry
}

\begin{abstract}
Grafting and budding are common horticultural techniques, and similar techniques have been successfully used in the management of tree wounds by bridge and approach grafting. The success of bark grafts raises the possibility of using bark patch grafts to span trunk wounds and pruning cuts. Fifty seedling trees from each of six commonly planted Australian native and exotic species-Acacia dealbata, Banksia integrifolia, Eucalyptus viminalis, Platanus $\times$ acerifolia, Quercus robur, and Pinus radiata-had circular plugs of bark removed from their stem using a \#3 cork borer ( $9 \mathrm{~mm}$ diameter). The plugs were lifted from the stem and then re-attached at one of four rotations $(0,90,180$, and 270 degrees) to the original cambial orientation in each of the four seasons.

While there was no successful re-attachment for Pinus radiata, the data for the successful re-attachment of the other five species showed that the most successful orientation for re-attachment was in the original position (0 degrees); successful attachment did occur at other orientations. The best season for re-attachment was spring, but successful attachment did occur in other seasons; success was lowest when grafting was undertaken in winter.

The use of bark patch grafts may provide arborists with an additional method for dealing with large wounds caused by vandalism and accidents, and would be particularly useful if a tree was of special, historic, or environmental significance to the landscape. Covering the wound with a bark patch graft may conceal the removal of a branch, hide obvious scarring, and at the same time reduce the risk of disease and stress to the tree by closing the wound more quickly than would normally occur due to natural callusing.

Key Words. Acacia dealbata; Australia; Banksia integrifolia; Bark Grafting; Callus; Eucalyptus viminalis; Native Tree Species; Pinus radiate; Platanus $\times$ acerifolia; Quercus robur; Seasonal Wound Responses; Tree Wound Closure.
\end{abstract}

In the urban environment, damage to trees may result from storms, human activity, or from structural defects (Pirone et al. 1988; Harris et al. 2004). Wounding also occurs from vehicle collisions, power-line clearing, building and construction activities, road works, and vandalism, all of which can cause damage ranging from minor scarring on trunks to limb removal and tears that remove large areas of bark. Pruning is also a common cause of bark damage, as improper pruning remains a major problem worldwide despite being relatively easy to prevent through the adoption of proper techniques and standards (Shigo 1986; Moore 1990; Standards Australia 2007). A successful response by a tree to wounding is usually through compartmentalization (Shigo and Marx 1977). Trees don't heal wounds (Shigo and Marx 1977; Shortle 1979), but rather confine or compartmentalize injured and infected wood (Shortle 1979) through wound closure and wound compartmentalization (Harris et al. 2004) that has been described in many tree species (McQuilkin 1950; Neely 1970; Shigo and Marx 1977; Kramer and Kozlowski 1979; Hudler 1984; Smith 1988; Biggs 1990; Harris et al. 2004).

One of a tree's early responses to wounding is the formation of callus tissue that can grow over wounds (Shigo and Marx 1977; Pirone et al. 1988; Moore 1990; Shigo 1991; Harris et al. 2004). Callus tissue is a mass of large, undifferentiated, homogeneous parenchyma cells that is formed at the margins of wounds and arises from cambial derivatives or from parenchyma cells of the phloem, cortex, or vascular rays, and from immature xylem rays (Esau 1965; Kramer and Kozlowski 1979). However, it mostly commonly derives from the cambium (Fahn 1985), 
and under certain circumstances, such cells can be described as the equivalent of stem cells in animal tissues (Vernoux and Benfey 2005; Dinneny and Benfey 2008). The production of callus is largely dependent on the interaction of phytohormones and particularly auxins, gibberellins, and cytokinins (Aloni et al. 2010; Aloni 2015). Callus formation is the basis of the formation of graft unions utilized in horticulture (Neely 1970; Shigo and Marx 1977; Hudler 1984; Perry and Hickman 1987; Mattheck and Korseska 1989; McDougall and Blanchette 1996; McGarry 2001).

Callus formation not only serves to reconnect vascular and other tissues across a wound (DavidSchwartz and Sinha 2007), but also has an important role in forming a cap on the external edges of the wound, closing them (Shigo 1986). The shape of a wound has little effect on the rate of wound closure, but its width does, with wounds less than 12 $\mathrm{mm}$ in diameter likely to close within a year (Neely 1970; Neely 1983). Closure occurs after the same length of time for similar-sized wounds (Neely 1970; Kramer and Kozlowski 1979; Harris et al. 2004), and wound closure rates correlate positively with rates of trunk growth but vary with species and years after wounding (Neely 1988b). More callus tissue was produced around large wounds than small and callus growth at the edge of the wound was shown to be greater than the radial growth of the stem. Wound size and location have an impact on the rates of wound closure (Neely 1988c). Once a mass of callus cells becomes lignified it is termed woundwood (Harris et al. 2004), and as it grows it eventually seals the wound. In small wounds, the callus tissue normally closes the wound quickly before woundwood can be formed. The formation of callus tissue, and subsequent woundwood, is part of the tree's defensive response to wounding.

The differentiation of callus into xylem or phloem tissues is largely controlled by the concentrations and interactions of the hormones auxin, gibberellins, cytokinins, and ethylene(Aloni2015). However, the importance of the auxin, indole3 -acetic acid (IAA), is of particular significance in vascular tissue differentiation and involves the basipetal movement of IAA (Sawchuk and Scarpella 2013). The auxin canalization hypothesis is based on mature tissue responses to applied auxin application, but is also consistent with cel- lular development in embryonic tissues and shoot organ development (Sawchuk and Scarpella 2013).

However, if the bark has been damaged, lost, or cannot be replaced, techniques such as bridge grafting, approach grafting, and inarching can be used for repairing damaged orchard and valuable ornamental trees (McGarry 2001; Goren et al. 2004; Harris et al. 2004; Hartmann et al. 2010). These techniques involve growing young seedlings that are progeny of the damaged plant, clones, or at least of the same species as the damaged plant around the base of the damaged tree. (Harris et al. 2004; Hartmann et al. 2010). These techniques require considerable skill and are expensive to undertake, but can be used to repair damaged ornamental trees of historic, heritage, cultural, landscape, environmental, and horticultural significance that warrant the expenditure.

\section{The Effect of Season on Tree Responses to Damage}

Tree wound healing rates in three species of deciduous trees and Eucalyptus camaldulensis were fastest during the active growth phase from midspring through to early summer (Neely 1970; Perry and Hickman 1987). Mercer (1979) described latewinter and spring as the seasons when wounds generally callus-over best. The slowest rates of wound closure occur in wounds made during late-autumn and early-winter (Neely 1970; Perry and Hickman 1987), and wounds inflicted in autumn may be detrimental to tree health because of the increased risk of infection, as many fungi sporulate at this time (Felix and Shigo 1977; Mercer 1979).

Callus cell division, enlargement and differentiation occur best from mid-winter through to summer, when sap flow is heavy. In regions with definite seasonal climates, the cambium may cease activity and become dormant for periods as long as from late-summer to early-spring (Fahn 1985). The cambium is often responsible for generating callus tissue, which means that a tree is best able to react to damage and close wounds at times of the year when the cambium is most active. The rate of wound closure in Prunus persica depended most on the average temperature after wounding (Biggs 1990); the warmer the temperature, the faster the healing (Kozlowski et al. 1991). Moisture stress 
and temperature have been shown to influence wound responses (Hudler and Banik 1986).

Callus production and wound closure can be expected to be greatest in spring and earlysummer (Clearwater et al. 2007). The large number of active young leaves gives rise to high levels of IAA, which moves basipetally; active root growth produces high levels of cytokinins, which move acropetally; while high levels of both stimulate callus production, especially if water and photosynthate are available (Aloni 2015). Good growth by plants at this time of the year increases the production of sugars, which act as signals that further stimulate IAA production, especially if there is rapid transpiration and available water (Lilley et al. 2012) The warmer temperatures also stimulate increased auxin and cytokinin production in young leaves and roots tips, respectively, which continues until very warm temperatures and/or reduced water supply change phytohormone production in response to stress (Aloni 2015). Such changes are significant in the subsequent differentiation of the callus.

\section{The Effect of Species on Tree Responses to Damage}

There is genetic control of wound closure (Shigo 1986; Kozlowski et al. 1991) and compartmentalization (Shigo and Marx 1977; Shortle 1979; David-Schwartz and Sinha 2007). There are large differences between tree species when it comes to the rate of wound responses after pruning (Mercer 1979). Significant variability in wound closure rates exists within tree populations (Neely 1988b), and the time it takes for the callus to complete wound closure varies with species (Neely 1988a). Not only does cambial activity differ from species to species, but the rate of formation of boundaries within a tree after wounding varies with species as well (Shigo 1986; Kramer and Kozlowski 1979; Kozlowski et al. 1991; Waisel 1991).

Variation also exists within trees of the same species, as identical wounds inflicted on trees of the same species, at the same time, have different rates of wound closure (Neely 1988b). It has been shown that some clones, or varieties of trees are particularly good at compartmentalizing, while other trees of the same species are poor (Mercer 1979; Shigo 1986; Santamour 1987a). Differences between and within plant species are to be expected as trees may be ring or diffuse porous and have vessels and tracheids of different diameter sizes, both of which can influence the free flow of phytohormones and so also their concentration in plant tissues (Aloni 2015). Furthermore, the growth rate of the individual tree can influence the production of and response to hormones. Grafting, which has been practiced for centuries, may have unwittingly assisted in the selection of strong compartmentalization as a characteristic of common horticultural species, as trees that graft successfully tend to be strong at wound compartmentalization (Shigo 1991).

\section{Grafting}

The process of grafting is based on the ability of the cambium, or other tissue, to form the callus at the junction of the joining tissues and relies on the callus differentiating to connect the xylem and phloem (McGarry 2001; Moore 2013). Successful grafts are usually between plants of the same genus; however, in some instances, plants of different genera, but of the same family, may be compatible (Moore 2013). The type of grafting that is particularly useful in relation to tree wounds is the bridge graft, which is used to restore sap flow in repairing the bark of a damaged tree trunk (Smith 2008). Bridge grafting, sometimes referred to as repair grafting (Smith 2008), is also used to repair bark damage to trees from grazing animals, such as deer, horses, and rabbits (Anonymous 2004). A number of scions are prepared and inserted under the intact bark across the wound. Most plants that can be grafted will respond successfully (Moore 2013), especially in early spring just as active growth of the tree is beginning and the bark is slipping easily (Hartmann et al. 2010).

Patch budding/grafting is a method of grafting that involves removing a square patch, containing one bud, from the scion and inserting it into a same-sized square wound that has been prepared in the rootstock. The relationship between scion and stock at the cellular level is becoming better understood (Koepke and Dhingra 2013), but the basipetal movement of IAA is a significant factor in the production and subsequent differentiation of callus and the vascular connection between scion and stock tissues (Grebe 2004; Aloni et al. 2010; Aloni 2015). Some of the seasonal influences observed on 
budding and grafting success can be explained by high production of IAA in early spring by young and actively growing leaves, which influences both callus production and differentiation (Aloni 2015)

Large bark patch grafts could be an alternative to bridge-grafting for spanning trunk wounds and pruning cuts. Girdling wounds can be bridged with bark implants or bridge grafts (Harris et al. 2004), so why not consider a bark patch grafting technique using bark patches cut from branches or other areas on the trunk of an affected tree? The patches should be cut with clean edges, positioned to ensure good cambial contact, and protected from desiccation (Priestly and Scott 1955; Fahn 1985; Hartmann et al. 2010), which can be achieved by covering the graft with materials such as grafting clay, wax or tape, rubber latex, paraffin wax, waxed cloth, plastic strips, and raffia (McGarry 2001; Hartmann et al. 2010). Proper orientation of the patch is important, as experiments have shown that tissues can be adversely affected if the orientation is changed from the original (Thair and Steeves 1976).

In 1991, a bark patch was attached to an Ulmus procera growing in the gardens of Burnley College, Melbourne, Australia, following the removal of a large branch. Before the branch was removed, a large flap of bark on the underside of the limb was carefully removed from contact with the limb, and when the limb was cut, the flap was folded upward and used as a bark patch to cover the wound (Figure 1). The connection of the patch with the tissue below it remained intact and the patch remained in place and healthy until the removal of the tree in 2014. The wound had been included and had successfully compartmentalized.

This successful bark patch graft precipitated this experiment which investigated whether bark patches could be removed and then successfully replaced on the same tree, whether there were differences between tree species in their responses, and whether the season when the damage and patch grafting was done had any effect of successful re-attachment. The bark patches used in the experiments were small and were done on seedling trees as a model system. However, the production of callus and its differentiation have been reported to be similar in studies on mature and embryonic tissues, callus-based research, and shoot organ development (Sawchuk and Scar-

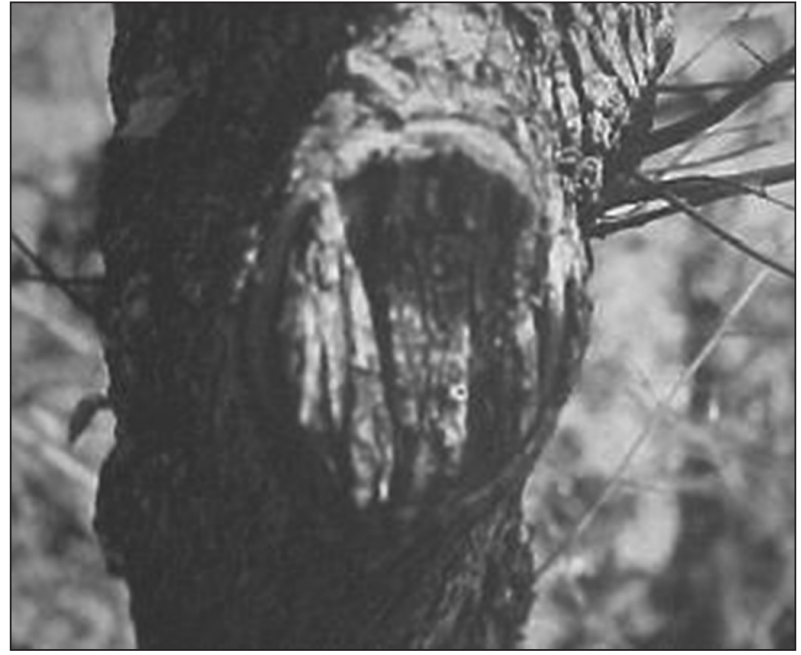

Figure 1. A bark graft patch, attached to the trunk of an Ulmus procera growing in Burnley Gardens, Australia (approximately $240 \mathrm{~mm}$ in diameter), 10 years prior to the photograph. Note the uniform ring of callus forming at the branch bark ridge.

pella 2013). Because plant responses to phytohormones occur at the cellular level, consistent tissue responses are to be expected (Nakamura et al. 2012; Koepke and Dhingra 2013). The experiments provided data that could inform the use of bark from damaged trees as a patch over parts of the trunk or branch stubs to facilitate rapid growing over and compartmentalization.

\section{MATERIALS AND METHODS}

Fifty trees from each of six species commonly planted in Australia streets and gardens, comprising both native and exotics-Acacia dealbata Link, Banksia integrifolia L.f., Eucalyptus viminalis Labill, Platanus $\times$ acerifolia (Air) Willd., Quercus robur L., and Pinus radiata D. Don.-were grown outdoors and maintained with regular irrigation and fortnightly liquid fertilizer applications of Phostrogen ${ }^{\otimes}$ at $74 \mathrm{mg} \mathrm{N} / \mathrm{L}$. Seedlings of $A$. dealbata, B. integrifolia, and E. viminalis were purchased as tubestock and potted to standard, black $150 \mathrm{~mm}$ pots. P. $\times$ acerifolia and Q. robur were sourced as bare-rooted material, and the $P . \times$ acerifolia were potted to standard $150 \mathrm{~mm}$ pots, and the $Q$. robur, with larger root systems, were potted into larger $300 \mathrm{~mm}$ squat pots sprayed with Spinout $^{\oplus}$ to reduce the likelihood of the trees becoming pot bound. Pinus radiata trees were sourced as "treelings" from in-ground cutting beds and pot- 
Table 1. Source, size and dates related to the six species used in Experiment 1.

\begin{tabular}{|c|c|c|c|c|}
\hline Species & $\begin{array}{l}\text { Nursery } \\
\text { of origin }\end{array}$ & $\begin{array}{l}\text { Seedling size } \\
\text { at purchase }\end{array}$ & $\begin{array}{l}\text { 1st bark } \\
\text { patch season }\end{array}$ & $\begin{array}{l}\text { Container } \\
\text { size }\end{array}$ \\
\hline Quercus robur & $\begin{array}{l}\text { Corella Nursery; } \\
\text { Kallista, Victoria }\end{array}$ & $\begin{array}{l}30 \mathrm{~cm}, \\
\text { bare-rooted }\end{array}$ & $\begin{array}{l}\text { Year } 1 \\
\text { mid-winter (July) }\end{array}$ & $\begin{array}{l}300 \mathrm{~mm} \\
\text { squat pot }\end{array}$ \\
\hline Platanus $\times$ acerifolia & $\begin{array}{l}\text { Corella Nursery; } \\
\text { Kallista, Victoria }\end{array}$ & $\begin{array}{l}20 \mathrm{~cm} \\
\text { bare-rooted }\end{array}$ & $\begin{array}{l}\text { Year } 1 \\
\text { mid-winter (July) }\end{array}$ & $200 \mathrm{~mm}$ pot \\
\hline Pinus radiata & $\begin{array}{l}\text { Amcor Cowwarr } \\
\text { Weir Nursery; } \\
\text { Cowwarr, Victoria }\end{array}$ & $\begin{array}{l}15-20 \mathrm{~cm} \\
\text { field-grown }\end{array}$ & $\begin{array}{l}\text { Year } 1 \\
\text { mid-autumn (April) }\end{array}$ & $200 \mathrm{~mm}$ pot \\
\hline $\begin{array}{l}\text { Eucalyptus viminalis } \\
\text { Acacia dealbata }\end{array}$ & $\begin{array}{l}\text { NRCL Nursery; } \\
\text { Springvale, Victoria }\end{array}$ & $\begin{array}{l}20-30 \mathrm{~cm} \\
\text { forestry tube }\end{array}$ & $\begin{array}{l}\text { Year } 1 \\
\text { mid-winter (July) }\end{array}$ & $200 \mathrm{~mm}$ pot \\
\hline Banksia integrifolia & $\begin{array}{l}\text { NRCL Nursery; } \\
\text { Springvale, Victoria }\end{array}$ & $\begin{array}{l}<20 \mathrm{~cm} \\
\text { forestry tube }\end{array}$ & $\begin{array}{l}\text { Year } 1 \\
\text { mid-autumn (April) }\end{array}$ & $200 \mathrm{~mm}$ pot \\
\hline
\end{tabular}

Table 2. Month for the commencement of each season's patch bark grafting trial ( $n=10$ for each treatment).

\begin{tabular}{|c|c|c|c|c|}
\hline Species & Plug graft \#1 & Plug graft \#2 & Plug graft \#3 & Plug graft \#4 \\
\hline $\begin{array}{l}\text { Quercus robur } \\
\text { Acacia dealbata } \\
\text { Eucalyptus viminalis } \\
\text { Platanus } \times \text { acerifolia }\end{array}$ & $\begin{array}{l}\text { Year } 1 \\
\text { mid-winter } \\
\text { (July) }\end{array}$ & $\begin{array}{l}\text { Year } 1 \\
\text { mid-spring } \\
\text { (October) }\end{array}$ & $\begin{array}{l}\text { Year } 1 \\
\text { mid-summer } \\
\text { (February) }\end{array}$ & $\begin{array}{l}\text { Year } 2 \\
\text { mid-autumn } \\
\text { (April) }\end{array}$ \\
\hline $\begin{array}{l}\text { Pinus radiata } \\
\text { Banksia integrifolia }\end{array}$ & $\begin{array}{l}\text { Year } 1 \\
\text { mid-autumn } \\
\text { (April) }\end{array}$ & $\begin{array}{l}\text { Year } 1 \\
\text { mid-winter } \\
\text { (July) }\end{array}$ & $\begin{array}{l}\text { Year } 1 \\
\text { mid-spring } \\
\text { (October) }\end{array}$ & $\begin{array}{l}\text { Year } 1 \\
\text { mid-summer } \\
\text { (February) }\end{array}$ \\
\hline
\end{tabular}

ted to standard $150 \mathrm{~mm}$ pots (Table 1). All trees ranged from $700-1000 \mathrm{~mm}$ in height with a stem caliper in excess of $15 \mathrm{~mm}$ diameter before treatments were commenced. Of the 50 trees grown, the largest 40 of each species were used in the experiments, with ten trees available in case any of the trees proved unsuitable in either size or health.

Circular plugs of bark were removed from the stem using a \#3 cork borer, which cut a $9 \mathrm{~mm}$ diameter plug of bark tissue (Figure 2). The plug was lifted from the stem and then re-attached at one of four rotations-0, 90, 180, and 270 degrees-to the original cambial orientation. The plugs were rotated to ascertain the importance of cambial orientation in the reconnection of the vascular tissues. To determine the effect of season, four different bark patch graft rotations were performed on each specimen tree of all species with 10 replicates. Each patch treatment was performed in the middle of each of the four seasons-spring, summer, autumn, and winter-so that each tree received four bark patch grafts at the same orientation (Table 2).

Once the bark plugs had been removed from the seedlings and then repositioned, they were held in position using budding tape. The tape holding the bark plug in place was removed two weeks later. Whether the bark plugs had successfully re-attached was monitored at 2, 4, 8, 16, 32 , and 64 weeks after grafting. The first treatments were imposed in mid-autumn of Year 1 on the $B$. integrifolia and $P$. radiata saplings, which were of suitable size. The other four species were treated in mid-winter of Year 1 when they had attained suitable size (Table 2). The trees remained in pots for the duration of the experiment.

In the early weeks after treatment, weeks 2 and 4, callus production was taken as being indicative of possible re-attachment, and was thus scored positively. After this time, however, the plugs were either attached to the surrounding bark so that they could not be dislodged or were falling out or easily dislodged with a probe at the time of inspection.

The experiment involved six species, ten replicates of which were subjected to four plug orientations in each of four seasons. There were 240 trees in total, and the data collected at weeks 2 and 32 were subjected to a logarithmic regression analysis to test the significance of seasonal, 


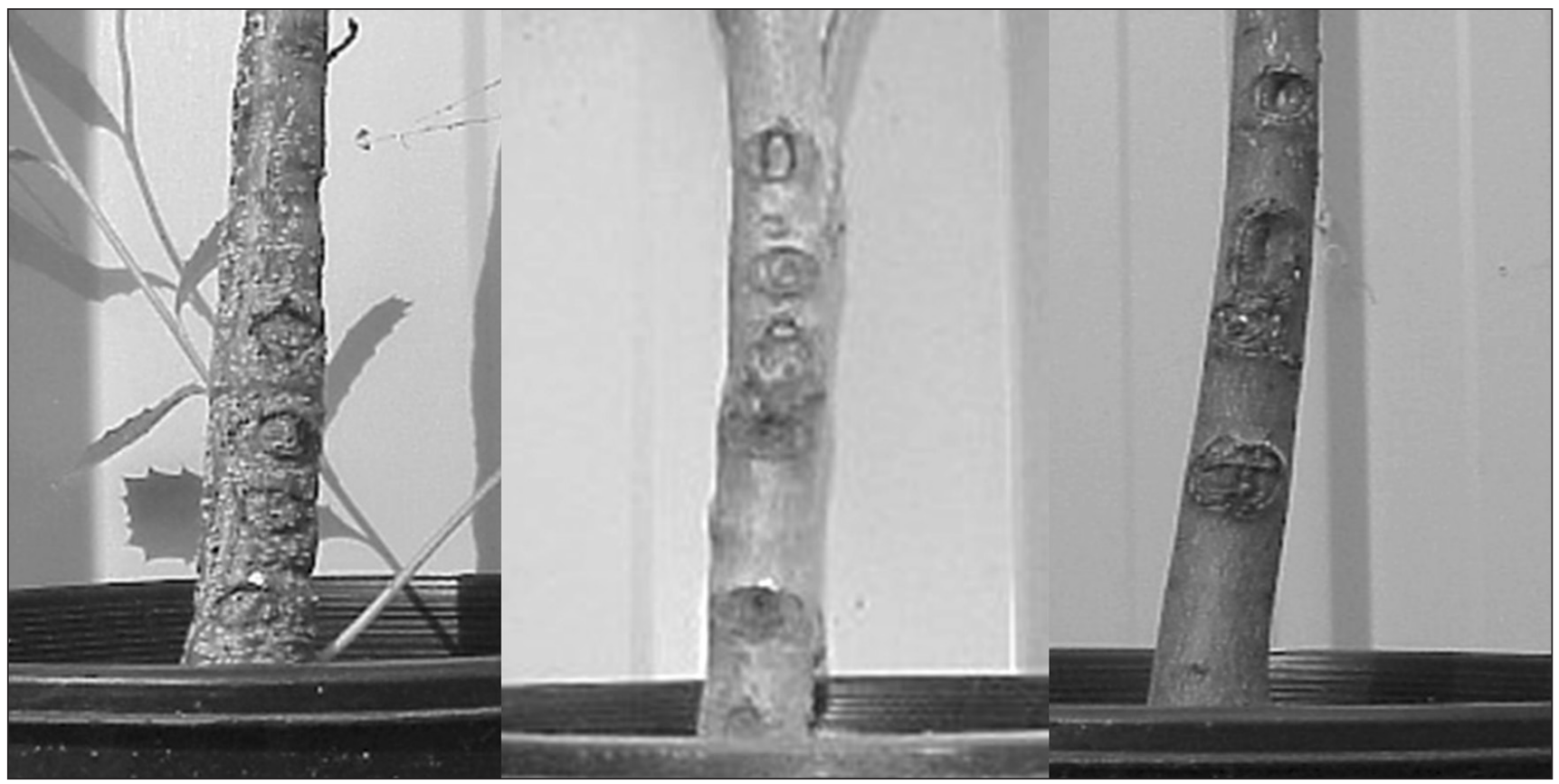

Figure 2. Examples of bark patch grafts on seedlings of Banksia integrifolia, Platanus $\times$ acerifolia, and Eucalyptus viminalis.

orientation, and species differences. These weeks were chosen because week 2 was immediately after the protective tape was removed, and by week 32, plugs had either re-attached or had failed. In the course of the experiment, four $P$. radiata, two Platanus $\times$ acerifolia, and three $Q$. robur plants died, but there were sufficient replicates of all species and treatments for statistical analysis.

\section{RESULTS}

The data for the successful re-attachment of the bark plugs for the six different species at different orientations show that the most successful orientation was in the original position (or 0 degrees), but successful attachment did occur at other orientations (Table 3; Figure 3; Figure 4). The best season for reattachment was spring (Table 4), but successful attachment did occur in other seasons. Successful attachment occurred in all species but $P$. radiata (Table 3 ; Table 5 ). The data demonstrate (Table 3; Table 4; Table 5) that with one exception (E. viminalis), if re-attachment was successful at 16 weeks, then the plugs were likely to remain attached and there was no change after week 32 for any species (Figure 4).

The results for bark plug re-attachment show that there was no success with Pinus radiata. Callus was produced for only a maximum 15\% of trees with the 0-degree orientations, but there was no attachment after eight weeks. The results for $P . \times$ acerifolia, showed a higher rate of successful bark patch graft re-attachment with orientations of 0,180 , and 270 degrees all having successful re-attachment in the range of $20 \%-25 \%$, but there was no success at the 90-degree orientation. Quercus robur had some successful re-attachment at all orientations initially, but most subsequently failed over time.

For $A$. dealbata, bark plugs re-attached at a rate of about $30 \%$ for the 0 -degree orientation, and for all other orientations the rates were between 5\%-10\%. Banksia integrifolia had the highest rates of successful re-attachment of the six species tested, especially for the 0 -degree orientation, which had $72.5 \%$ of the bark plugs remaining attached for the duration of the experiment. However, attachment was above $27 \%$ for all orientations. For E. viminalis, more than $50 \%$ of the 0 -degree orientation bark plugs successfully reattached, and even the 180-degree orientation re-attached at a rate of $17.5 \%$. Curiously, the rates for 90 and 270 degrees were very low.

While it is difficult to generalize about the influence of season, without considering species and orientation, winter and spring appeared to be the best seasons for most species for re-attachment. 

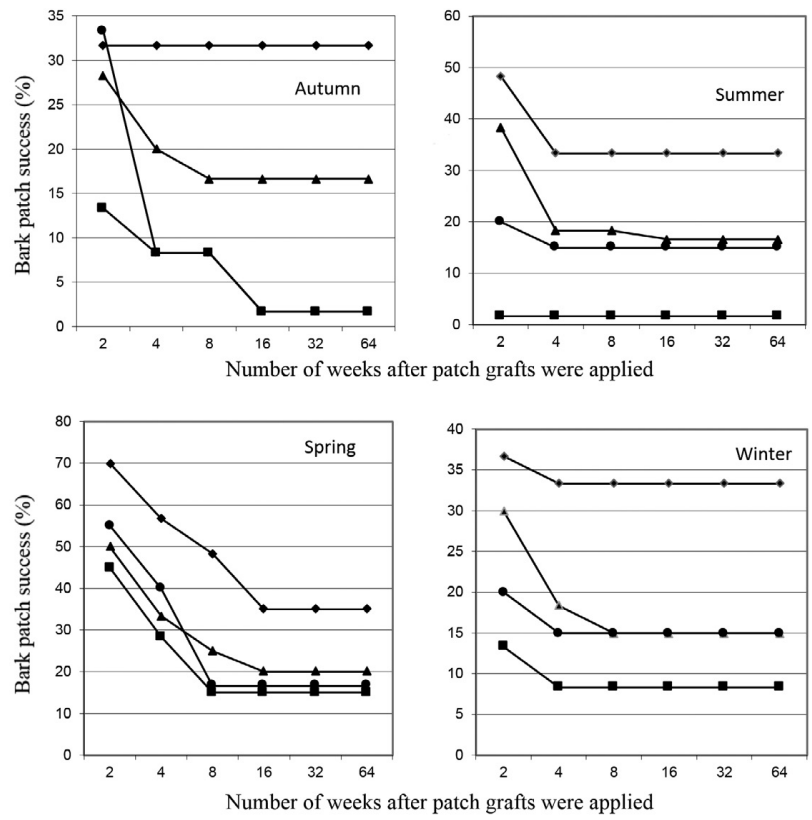

Figure 3. Success of patch grafts for six species of trees at four different orientations for four seasons:

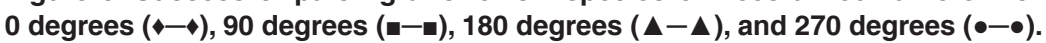
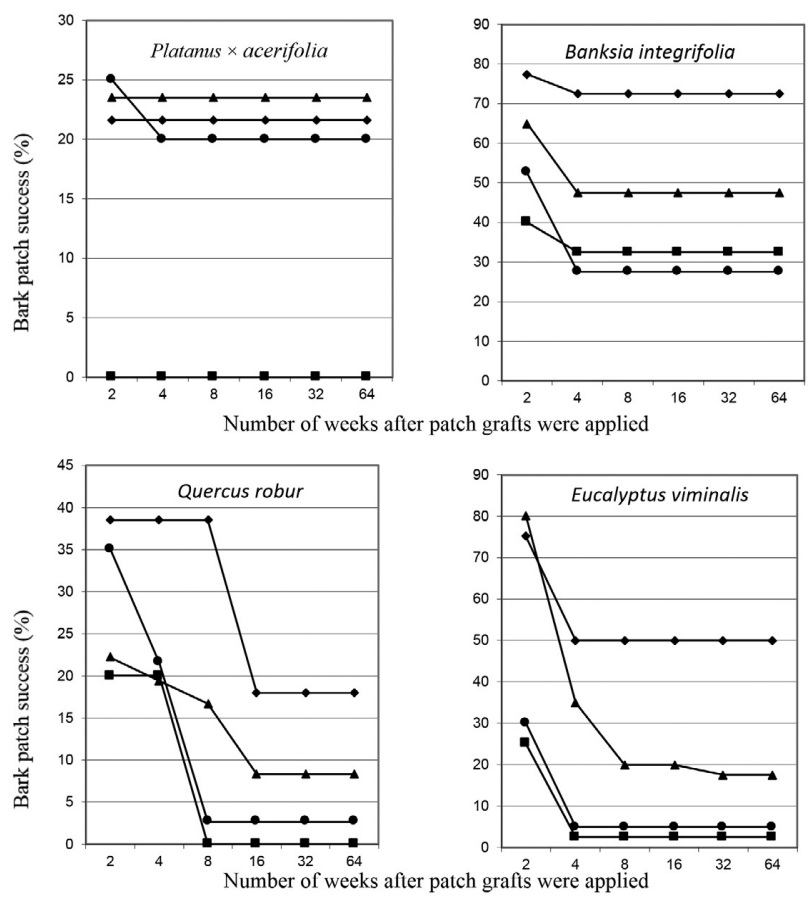

Figure 4. Success of patch grafts for Platanus $\times$ acerifolia, Banksia integrifolia, Quercus robur, and Eucalyptus viminalis at different orientations across all seasons: 0 degrees ( $-\downarrow), 90$ degrees ( $\square-\square), 180$ degrees $(\boldsymbol{\Delta}-\mathbf{\Delta})$, and 270 degrees $(\bullet-\bullet)$. 
Table 3. Success (\%) of bark plug re-attachment in six tree species, 2, 4, 8, 16, 32, and 64 weeks after treatment after orientating the plugs at $0,90,180$, and 270 degrees to their original position ( $n=10$ for each treatment).

\begin{tabular}{|c|c|c|c|c|c|c|c|c|c|c|c|c|}
\hline \multirow[t]{2}{*}{ Weeks } & \multicolumn{4}{|c|}{ Pinus radiata } & \multicolumn{4}{|c|}{ Banksia integrifolia } & \multicolumn{4}{|c|}{ Platanus $\times$ acerifolia } \\
\hline & 0 & 90 & 180 & 270 degrees & 0 & 90 & 180 & 270 degrees & 0 & 90 & 180 & 270 degrees \\
\hline 2 & 15 & 0 & 0 & 0 & 77.5 & 40 & 65 & 52.5 & 21.6 & 0 & 23.5 & 25 \\
\hline 4 & 15 & 0 & 0 & 0 & 72.5 & 32.5 & 47.5 & 27.5 & 21.6 & 0 & 23.5 & 20 \\
\hline \multirow[t]{3}{*}{$8,16,32,64$} & 0 & 0 & 0 & 0 & 72.5 & 32.5 & 47.5 & 27.5 & 21.6 & 0 & 23.5 & 20 \\
\hline & \multicolumn{4}{|c|}{ Quercus robur } & \multicolumn{4}{|c|}{ Acacia dealbata } & \multicolumn{4}{|c|}{ Eucalyptus viminalis } \\
\hline & 0 & 90 & 180 & 270 degrees & 0 & 90 & 180 & 270 degrees & 0 & 90 & 180 & 270 degrees \\
\hline 2 & 38.5 & 20 & 22.2 & 35.1 & 50 & 25 & 35 & 32.5 & 75 & 25 & 80 & 30 \\
\hline 4 & 38.5 & 20 & 19.4 & 21.6 & 37.5 & 15 & 17.5 & 32.5 & 50 & 2.5 & 35 & 5 \\
\hline 8 & 38.5 & 0 & 16.7 & 2.7 & 37.5 & 15 & 12.5 & 15 & 50 & 2.5 & 20 & 5 \\
\hline $16,32,64$ & 18 & 0 & 8.3 & 2.7 & 37.5 & 15 & 12.5 & 5 & 50 & 2.5 & 20 & 5 \\
\hline
\end{tabular}

Table 4. Success (\%) of bark plug re-attachment, $2,4,8,16,32$, and 64 weeks after treatment after orientating the plugs at $0,90,180$, and 270 degrees to their original position in winter, spring, summer, and autumn ( $n=10$ for each treatment).

\begin{tabular}{|c|c|c|c|c|c|c|c|c|}
\hline \multirow[t]{2}{*}{ Weeks } & \multicolumn{4}{|l|}{ Winter } & \multicolumn{4}{|c|}{ Spring } \\
\hline & 0 & 90 & 180 & 270 degrees & 0 & 90 & 180 & 270 degrees \\
\hline 2 & 36.67 & 13.33 & 30 & 20 & 70 & 45 & 50 & 55 \\
\hline 4 & 33.33 & 8.33 & 18.33 & 15 & 56.67 & 28.33 & 33.33 & 40 \\
\hline 8 & 33.33 & 8.33 & 15 & 15 & 48.33 & 15 & 25 & 16.67 \\
\hline \multirow[t]{3}{*}{$16,32,64$} & 33.33 & 8.33 & 15 & 15 & 35 & 15 & 20 & 16.67 \\
\hline & \multicolumn{4}{|c|}{ Summer } & \multicolumn{4}{|c|}{ Autumn } \\
\hline & 0 & 90 & 180 & 270 degrees & 0 & 90 & 180 & 270 degrees \\
\hline 2 & 48.33 & 1.67 & 38.33 & 20 & 13.33 & 28.3 & 33.33 & 13.33 \\
\hline 4 & 33.33 & 1.67 & 18.33 & 15 & 8.33 & 20 & 8.33 & 8.33 \\
\hline 8 & 33.33 & 1.67 & 18.33 & 15 & 8.33 & 16.67 & 8.33 & 8.33 \\
\hline $16,32,64$ & 33.33 & 1.67 & 16.67 & 15 & 1.67 & 16.67 & 1.67 & 1.67 \\
\hline
\end{tabular}

Table 5. Success (\%) of bark plug re-attachment in six tree species 2, 4, 8, 16, 32, and 64 weeks after treatment after orientating in winter, spring, summer, and autumn $(n=10$ for each treatment).

\begin{tabular}{|c|c|c|c|c|c|c|c|c|c|c|c|c|}
\hline \multirow[t]{2}{*}{ Weeks } & \multicolumn{4}{|c|}{ Pinus radiata } & \multicolumn{4}{|c|}{ Banksia integrifolia } & \multicolumn{4}{|c|}{ Platanus $\times$ acerifolia } \\
\hline & Win & Spr & Sum & Aut & Win & Spr & Sum & Aut & Win & Spr & Sum & Aut \\
\hline 2 & 0 & 15.0 & 0 & 0 & 52.5 & 87.5 & 10.0 & 85.0 & 0 & 2.50 & 62.5 & 0 \\
\hline 4 & 0 & 15.0 & 0 & 0 & 45.0 & 87.5 & 7.5 & 40.0 & 0 & 2.50 & 57.5 & 0 \\
\hline \multirow[t]{3}{*}{$8,16,32,64$} & 0 & 0 & 0 & 0 & 45.0 & 87.5 & 7.5 & 40.0 & 0 & 2.50 & 57.5 & 0 \\
\hline & \multicolumn{4}{|c|}{ Quercus robur } & \multicolumn{4}{|c|}{ Acacia dealbata } & \multicolumn{4}{|c|}{ Eucalyptus viminalis } \\
\hline & Win & Spr & Sum & Aut & Win & Spr & Sum & Aut & Win & Spr & Sum & Aut \\
\hline 2 & 10.0 & 70.0 & 10.0 & 20 & 10.0 & 62.5 & 27.5 & 42.5 & 57.5 & 90.0 & 52.5 & 10.0 \\
\hline 4 & 10.0 & 67.5 & 10.0 & 7.5 & 10.0 & 27.5 & 22.5 & 42.5 & 35.0 & 40.0 & 7.5 & 10.0 \\
\hline 8 & 10.0 & 27.5 & 10.0 & 7.5 & 10.0 & 10.0 & 22.5 & 37.5 & 30.0 & 30.0 & 7.5 & 10.0 \\
\hline $16,32,64$ & 10.0 & 0 & 10.0 & 7.5 & 10.0 & 10.0 & 22.5 & 17.5 & 30.0 & 30.0 & 5.0 & 10.0 \\
\hline
\end{tabular}

Autumn was the least likely season for success for deciduous species; however, successful re-attachment could be achieved in all seasons.

Logarithmic regression analysis of the data at weeks 2 and 32 showed (Table 6) that there were no significant differences for the interaction of season, plug orientation, and species except for week 2 data for summer and autumn where $P<0.05$. However, there were signifi- cant differences $(P<0.05)$ when orientation and species were considered for the different seasons for weeks 2 and 32. There were also significant differences for orientation, except for spring, where the $P$ values were slightly greater than 0.05 for both week 2 and 32. There were significant differences for all seasons for all species with $P<0.05$ for both data sets. 
Table 6. Logarithmic regression analysis of patch graft success at 2 and 32 weeks for all species, orientations, and seasons using the logarithmic likelihood of the model fitted $(n=10$ for each treatment).

\begin{tabular}{|c|c|c|c|c|c|c|c|c|c|}
\hline & & Logarith & ic likelih & for logari & ic regressi & & & & \\
\hline & & Winter & & Spring & & Summe & & Autumn & \\
\hline Week & & 2 & 32 & 2 & 32 & 2 & 32 & 2 & 32 \\
\hline Full model & & -56.97 & -57.97 & -79.52 & -43.77 & -44.16 & -45.32 & -53.71 & -39.12 \\
\hline Orientation + species & & -63.60 & -65.52 & -90.62 & -46.38 & -61.81 & -50.91 & -68.38 & -48.03 \\
\hline Species & & -80.96 & -77.97 & -97.94 & -57.11 & -100.31 & -75.94 & -76.26 & -68.62 \\
\hline Patch & & -114.34 & -93.95 & -157.49 & -118.11 & -111.75 & -89.88 & -131.64 & -72.32 \\
\hline & & $P$-values & erived fr & mic regre & $n$ analysis & & & & \\
\hline & & $\underline{\text { Winter }}$ & & Spring & & Summe & & Autumn & \\
\hline Week & & 2 & 32 & 2 & 32 & 2 & 32 & 2 & 32 \\
\hline Parameter & $\mathrm{df}$ & & & & & & & & \\
\hline Interaction & $\overline{15}$ & 0.582 & 0.419 & 0.102 & 0.990 & 0.002 & 0.739 & 0.015 & 0.272 \\
\hline Orientation/species & 3 & 0.001 & 0.001 & 0.002 & 0.001 & 0.001 & 0.001 & 0.001 & 0.001 \\
\hline Species/orientation & 5 & 0.001 & 0.001 & 0.001 & 0.001 & 0.001 & 0.001 & 0.001 & 0.001 \\
\hline Species & 5 & 0.001 & 0.001 & 0.001 & 0.001 & 0.001 & 0.001 & 0.001 & 0.001 \\
\hline Orientation & 3 & 0.001 & 0.001 & 0.053 & 0.056 & 0.001 & 0.001 & 0.034 & 0.001 \\
\hline
\end{tabular}

\section{DISCUSSION}

In all seasons, the highest rates of bark plug reattachment was at an orientation of 0 degrees, which was to be expected. For several species, inverting the original orientation of the bark plug (180 degrees) yielded the second highest rate of successful re-attachment. Orientation of 90 and 270 degrees were generally the least successful, and their rates were different. The successful re-attachment at other orientations is surprising given the complexity of the phloem and bark tissues involved (Grebe 2004), but can perhaps be explained by the juvenile nature of the trees used in the experiments and the plasticity of callus tissue (David-Schwartz and Sinha 2007).

Polarity is an important aspect of successful budding and grafting, and the directional movement of hormones contributes to their effects on plant tissues (Hartmann et al. 2010; Yin 2012). Based on research into budding and grafting success (Grebe 2004; Aloni 2015), it was not expected that rotating the bark patch plugs through 90,180 , or 270 degrees would have resulted in successful re-attachment. However, there were successes, which suggest that over the volumes of plant tissue that the patches involved there were sufficient concentrations of IAA and cytokinins for callus production. The species differences in the responses to patch rotation were consistent with research showing that different species can respond differently to hormone concentrations that are influenced by the rate of transport and the sizes of the cells through which they are transported (Olmstead et al. 2006; Sawchuk and Scarpella 2013; Aloni 2015).

Different species responded differently to the treatments imposed, which is consistent with research showing that there are important species differences in cambial activity and callus formation (Kramer and Kozlowski 1979; Mercer 1979; Santamour 1987b; Neely 1988b; Shigo 1991; David-Schwartz and Sinha 2007; Olmstead et al. 2006). Banksia integrifolia proved well-suited to the bark plug treatments, and there were high rates of attachment for all orientations and for most seasons, except summer. In contrast, for $P$. radiata, all of the bark plugs remained unattached. This species is particularly resinous and quickly deposited significant quantities of resin in the wound area, completely sealing the cork borer wounds and making re-attachment difficult. The resin acts as a barrier to the rapid diffusion and transport of hormones such as IAA by blocking xylem tissue, and so callus production is low (Aloni 2015).

Given that these treatments were imposed as a means of providing data on the potential for successfully grafting bark on wounded trees, the successful re-attachment of bark plugs at all orientations indicates that while tissue alignment does have an effect on the success of bark plug re-attachments, the tissues do not necessarily have to be aligned perfectly (Thair and Steeves 1976). What this means for an arborist is that there is some margin for operator error when grafting bark tissue in the field. Similarly, when considering seasonal effects, while spring would appear to 
be optimal for successful bark plug re-attachment, there can be success at other times of the year. This may be important, as a practicing arborist cannot choose the time of year that wounds occur and need treatment. This also widens the opportunity for arborists to consider attempting bark grafting for most species; however, grafting deciduous species in winter is unlikely to prove successful.

The statistical analysis of data for weeks 2 and 32 using logarithmic regression investigated whether successful re-attachment depended on i) species, ii) plug orientation, and iii) an interaction between species and plug orientation. In all cases except for autumn week 2 and summer week 2 , successful plug re-attachment depended on both species and orientation. The data for autumn week 2 and summer week 2 indicated that success depended on species or orientation. However, the data for week 2 were early in the experiment and were not always indicative of the long-term success of re-attachment, but data obtained on success at week 32 did not change thereafter.

The use of small bark patch plugs and seedling trees as a model system for investigating the behavior of larger trees has limitations, but it also has advantages. Research suggests that the interaction of phytohormones and cambial tissue in the production of callus is consistent in plant tissues regardless of age (Nakamura et al. 2012; Koepke and Dhingra 2013; Sawchuk and Scarpella 2013; Aloni 2015). Furthermore, by using small plugs, the concerns over using vertically aligned multiple plugs is reduced, as one is unlikely to get variation in hormone concentrations that might impact on tissue responses and callus production if wounds and plugs were larger, because the volume over which the hormones are transported and diffuse is small, which provides a consistent and even concentration (Aloni 2015).

The practical issue of where one gets material for the bark patch can be resolved if the patch is to be placed over a living branch, as the material can be sourced from the branch itself(Figure 1). If the patch is to be placed on the trunk, then the bark may be sourced from a branch that would be sacrificed and patched, or as in repair or bridge grafting, material may be specifically grown for patch grafting using clones or seedlings of the same parent plant or trees of the same species (Smith 2008; Moore 2013).
Overall, the results of the experiment are conclusive. The comparatively poor re-attachment rates at 90 and 270 degree orientations confirm that attempting to replace bark tissue at the right orientation enhances the potential of successful re-attachment in all seasons, and greatest success was achieved when tissues were re-attached at their original orientation in spring. Spring appeared to be the best season for patch grafting, perhaps because increased sap flow allowed rapid callus growth (Neely 1988a; Clearwater et al. 2007). Increased sap flow may also affect the viability of attached patches by shortening the time taken for a viable graft union to form.

Bark patch grafts need protection from desiccation for the first two to four weeks after grafting, which is consistent with well-documented horticultural grafting procedures (McDougall and Blanchette 1996; Hartmann et al. 2010). Grafts larger than $100 \mathrm{~mm}$ in diameter may also need to be secured in position. The following are suggestions for successful patch graft re-attachment:

- Bark patch grafts should be applied to a trunk wound or branch stub as soon as possible after wounding or pruning.

- The wound site needs to be kept clean and moist while preparing the bark patch graft. The material for the patch may come from the damaged bark, or from fresh bark taken from a limb removed from the tree.

- The edges of the wound and the bark patch graft must be as clean and neat as possible to ensure good cambial contact and to minimize the risk of disease.

- The bark patch grafts should be placed in cambial contact that ensures the maximum amount of cambial alignment.

- The orientation of the tissue should be as close as possible to the original (0-degree change).

- The bark patch graft should be tightly covered with budding tape (or similar) for at least two weeks, and up to four weeks.

- If the bark patch graft is not attached when the wound area is uncovered, remove the patch and allow natural callus growth to enclose the wound.

- Bark patch grafts are most successful in spring, so every effort should be made to perform elective bark patch grafts during this season. 
The use of bark patch grafts may mean that the removal of a tree limb could be less of an eyesore. Covering the wound with a bark patch graft conceals the fact that a limb has been removed and hides obvious scarring, while at the same time the risk of disease and stress to the tree may be reduced by closing the wound more quickly than would normally occur due to natural callusing. The use of bark patch grafts provides arborists with a method of dealing with tree trunk wounds caused by vandalism and accidents, and would be particularly useful if a tree was of special, historic, or environmental significance to the landscape.

Acknowledgments. Dr. Sue Finch of the University of Melbourne Statistics Consulting Centre is thanked for her assistance with the statistical analysis of data. Dr. E. Moore, linguist, is thanked for her helpful suggestions on reading the manuscript.

\section{LITERATURE CITED}

Aloni, B., R. Cohen, L. Karni, H. Aktas, and M. Edelstein. 2010. Hormonal signaling in rootstock-scion interactions. Scientia Horticulturae 127:119-126.

Aloni, R. 2015. Ecophysiological implications of vascular differentiation and plant evolution. Trees 29:1-16.

Anonymous. 2004. Recognizing types of mammal damage to trees and woodland Forestry Commission, United Kingdom. <www. forestry.gov.uk/fr/infd-6k4kaf>

Biggs, A.R. 1990. Managing wound-associated diseases by understanding wound healing in the bark of woody plants. Journal of Arboriculture 16:108-112.

Clearwater, M.J., P. Blattmann, Z. Luo, and R.G. Lowe. 2007. Control of scion vigor by kiwifruit rootstocks is correlated with spring root pressure phenology. Journal of Experimental Botany 58(7):1741-1751.

David-Schwartz, R., and N. Sinha. 2007. Evolution and development in plants: Bridging the gap. International Journal of Plant Sciences 168:49-59.

Dinneny, J.R., and P.N. Benfey. 2008. Plant stem cell niches: Standing the test of time. Cell 132:553-557.

Esau, K. 1965. Plant Anatomy, second edition. John Wiley and Sons, Inc, New York, New York, U.S.

Fahn, A. 1985. Plant Anatomy, third edition. Pergamon Press, New York, New York, U.S.

Felix, R., and A.L. Shigo. 1977. Rots and Rods. Journal of Arboriculture 3:187-190.

Goren, R., M. Huberman, and E.E. Goldschmidt. 2004. Girdling: Physiological and horticultural aspects. Horticultural Reviews 30:1-36.

Grebe, M. 2004. Ups and downs of tissue and planar polarity in plants. Bioessays 26:719-729.

Harris, R.W., N. Matheny, and J.R. Clark. 2004. Arboriculture. Integrated Management of Tree Shrubs and Vines in the Landscape, fourth edition. Prentice Hall, New Jersey, U.S.
Hartmann, H.T., D.E. Kester, F.J. Davies, and R.L. Geneve. 2010. Plant Propagation: Principles and Practices, eighth edition. Prentice Hall, New Jersey, U.S.

Hudler, G.W. 1984, Wound healing in the bark of woody plants. Journal of Arboriculture 10:241-245.

Hudler, G.W., and M.T. Banik. 1986. Wound repair and disease resistance in stems of Pachysandra terminalis. Canadian Journal of Botany 64:2406-2410.

Koepke, T., and A. Dhingra. 2013. Rootstock scion somatogenetic interactions in perennial composite plants. Plant Cell Reports 32:1321-1337.

Kozlowski, T.T., P.J. Kramer, and S.G. Pallardy. 1991. The Physiological Ecology of Woody Plants. Academic Press Inc, New York, U.S.

Kramer, P.J., and T.T. Kozlowski. 1979. Physiology of Woody Plants. Academic Press, New York, U.S.

Lilley, J.L., C.W. Gee, I. Sairanen, K. Ljung, and J.L. Nemhauser. 2012. An endogenous carbon-sensing pathway triggers increased auxin flux and hypocotyls elongation. Plant Physiology160:2261-2270.

McDougall, D.N., and R.A. Blanchette. 1996. Polyethylene plastic wrap for tree wounds: A promoter of wound closure on fresh wounds. Journal of Arboriculture 22:206-210.

McGarry, P.J. 2001. Bark Grafting as a Method of Wound Treatment in Urban Trees, Master of Applied Science (Horticulture) Thesis, University of Melbourne, Australia.

McQuilkin, W.E. 1950. Effects of some growth regulators and dressings on the healing of tree wounds. Journal of Forestry 48:423-428.

Mattheck, C., and G. Korseska. 1989. Wound healing in a plane (Platanus acerifolia)-An experimental proof of its stimulation. Arboricultural Journal 13:211-218.

Mercer, P.C. 1979. Attitudes to pruning wounds. Arboricultural Journal 3:457-465.

Moore, G.M. 1990. Tree Care for the Home Gardener. Lothian Publishing, Melbourne, Australia.

Moore, G.M. 2013. Ring-barking and Girdling: How much vascular connection do you need between Roots and Crown? Proceedings of the Fourteenth National Street Tree Symposium, 87-96. University of Adelaide/Waite Arboretum, Adelaide, Australia.

Nakamura, M., C.S. Kiefer, and M. Grebe. 2012. Planar polarity and planar morphogenesis in plants. Current Opinion in Plant Biology 15:593-600.

Neely, D. 1970. Healing of wounds on trees. Journal of the American Society of Horticultural Science 95:536-540.

Neely, D. 1983. Tree trunk growth and wound closure. Horticultural Science 18:99-100.

Neely, D. 1988a. Tree wound closure. Journal of Arboriculture 14:148-152.

Neely, D. 1988b. Wound closure rates on trees. Journal of Arboriculture 14:250-254.

Neely, D. 1988c. Closure of branch pruning wounds with conventional and 'Shigo' cuts. Journal of Arboriculture 14:261-264.

Olmstead, M.A., N.S. Lang, G.A. Lang, F.W. Ewers, and S.A. Owens. 2006. Examining the vascular pathway of sweet cherries grafted onto dwarfing rootstocks. HortScience 41(3):674-679.

Perry, E., and G. Hickman. 1987. Wound closure in Eucalypts. Journal of Arboriculture 13:201-202. 
Pirone, P.P., J.R. Hartman, M.A. Sall, and T.P. Pirone. 1988. Tree Maintenance, sixth edition. Oxford University Press, New York, New York, U.S.

Priestly, J.H., and L.I. Scott. 1955. An Introduction to Botany, third edition. Longmans, Green and Co, London, New York, Toronto.

Santamour, Jr., F.S. 1987a. Building walls and breaching walls: Truth and consequences in wound compartmentalization. Journal of Arboriculture 13:262-266.

Santamour, Jr., F.S. 1987b. Wound compartmentalization potential and borer damage in green ash. Journal of Arboriculture 13:131-134.

Sawchuk, M.G., and E. Scarpella. 2013. Polarity, continuity, and alignment in plant vascular strands. Journal of Integrated Plant Biology 55:824-834.

Shigo, A.L., and H.G. Marx. 1977. Compartmentalization of decay in trees. USDA Forest Service Bulletin No.405.

Shigo, A.L. 1986. A New Tree Biology: Facts, photos, and philosophies on trees and their problems and proper care. Shigo and Trees, Associates, Durham, New Hampshire.

Shigo, A.L. 1991. Modern Arboriculture - A systems approach to the care of trees and their associates. Shigo and Trees, Associates, Durham, New Hampshire, U.S.

Shortle, W.S. 1979. Tree care: A new look. Journal of Arboriculture $5: 281-284$.

Smith, C.W. 2008. Repairing damaged tree New Mexico State University Extension service. Bark. <http://aces.nmsu.edu/ces/yard/ 2007/090807.html>

Smith, K.T. 1988, Wounding, compartmentalization, and treatment tradeoffs. Journal of Arboriculture 14:226-229.

Standards Association of Australia. 2007. Pruning of amenity trees. AS4373-2007, Standards Association of Australia, North Sydney. pp. 281-284.

Thair, B.W., and T.A. Steeves. 1976. Response of the vascular cambium to reorientation in patch grafts. Canadian Journal of Botany 54:361-373.

Vernoux, T., and P.N. Benfey. 2005. Signals that regulate stem cell activity during plant development. Current Opinion in Genetics and Development 15:388-394.

Waisel, Y. 1991. Adaptation to salinity. In: A.S. Raghavendra (Ed.). Physiology of Trees. John Wiley \& Sons Inc, New York, U.S.

Yin, H, B. Yan, J. Sun, P. Jia, Z. Zhang, X. Yan, J. Chai, et al. 2012 Graft-union development: A delicate process that involves cellcell communication between scion and stock for local auxin accumulation. Journal of Experimental Botany 63:4219-4232.

\author{
G.M. Moore \\ University of Melbourne \\ Burnley College \\ 500 Yarra Boulevard \\ Richmond, Victoria, Australia, 3121 \\ gmmoore@unimelb.edu.au
}

\author{
P.G. McGarry \\ Huntingdale Golf Club \\ Windsor Avenue \\ Oakleigh South, Victoria, Australia, 3167
}

Résumé. Le greffage sous écorce et le bourgeonnement sont des techniques horticoles usuelles, et des techniques similaires ont été utilisées avec succès dans la gestion des plaies d'arbres par le greffage en pont et le greffage par rapprochement. Le succès des greffons sous écorce rehausse la possibilité de recourir à l'utilisation de plaquettes d'écorce greffées afin de recouvrir les plaies au tronc et les coupes d'élagage. Des plaquettes circulaires d'écorce furent retirés, à l'aide d'un perce-bouchon $\mathrm{n} 3$ (9 $\mathrm{mm}$ de diamètre), du tronc de cinquante arbres originant de semis et représentant chacune de six espèces australiennes indigènes et introduites fréquemment plantées, soit Acacia dealbata, Banksia integrifolia, Eucalyptus viminalis, Platanus $\times$ acerifolia, Quercus robur et Pinus radiata. Les plaquettes furent soulevées des tiges et aussitôt replacées selon l'une des quatre rotations $(0,90,180$ et 270 degrés) par rapport à l'orientation cambiale originale et ce, au cours de chacune des quatre saisons.

Bien qu'il n'y ait pas eu de regreffage couronné de succès chez le Pinus radiata, les données de regreffage réussi pour les cinq autres espèces ont cependant montré que l'orientation la plus fructueuse pour le regreffage était l'orientation d'origine (0 degré); du regreffage s'est tout de même produit avec d'autres orientations. La meilleure saison pour le regreffage fut le printemps, mais il y a eu des regreffages observés durant les autres saisons; les regreffages les moins réussis sont survenus en période hivernale.

L'utilisation de plaquettes d'écorce pour le greffage peut fournir aux arboriculteurs une technique supplémentaire pour traiter les grosses plaies causées par le vandalisme et les accidents, et se révèlerait particulièrement utile si un arbre possédait une valeur particulière, historique ou environnementale dans le paysage. La recouvrement d'une plaie avec un greffon d'écorce peut dissimuler l'enlèvement d'une branche, cacher des cicatrices évidentes et dans un même temps, réduire le risque de maladie et de stress subi par l'arbre en refermant la plaie plus rapidement que ce qui se produirait normalement suite à la formation d'un cal naturel.

Zusammenfassung. Stecklings- und Knospenveredelung sind gewöhnliche gärtnerische Techniken and ähnliche Techniken wie die Überbrückungsveredelung wurden erfolgreich bei der Behandlung von Baumwunden verwendet. Der Erfolg von Rindenreparaturen eröffnet die Möglichkeit, Rindenverpflanzungen bei der Behandlung von Stammwunden und Schnittwunden zu verwenden. Fünfzig Sämlingsbäumen von jeder von sechs häufig gepflanzten, in Australien einheimischen und exotischen Baumarten: -Acacia dealbata, Banksia integrifolia, Eucalyptus viminalis, Platanus $\times$ acerifolia, Quercus robur, und Pinus radiata- wurden kreisrunde Rindenstücke mit einem $9 \mathrm{~mm}$ Korkenbohrer entfernt. $\mathrm{Zu}$ allen vier Jahreszeiten wurden die Platten vom Stamm abgenommen und wieder aufgesetzt mit einer von vier Rotationen $(0,90,180$, und $270 \mathrm{Grad}$ ) zur ursprünglichen Orientierung des Kambiums.

Während es bei der Pinus radiata kein erfolgreiches Wiederanwachsen gab, zeigten die Daten über ein erfolgreiches Wiederanwachsen bei den anderen fünf Arten, dass die erfolgreichste Orientierung der Wiederanbringung des Rindenstücks die originale Position (0 Grad) war. Erfolgreiches Anwachsen kam auch bei anderen Orientierungen vor. Die beste Saison für Wiederanbringung war der Frühling, aber es kam auch in anderen Jahreszeiten vor, dass das Anwachsen erfolgreich war. Den geringsten Erfolg wies die Behandlung im Winter auf.

Der Einsatz von Rindentransplantationen liefert den Arboristen eine neue Methode zur Behandlung von großen Wunden, die durch Unfälle oder Vandalismus entstanden sind und würde besonders nützlich sein, wenn ein Baum von besonderer historischer Bedeutung oder Naturdenkmal und bedeutungsvoll in seiner Umgebung ist. Das Bedecken einer Wunde mit einem Rindenpflaster könnte die Astungswunde versiegeln, Schrammen an der Rinde verbergen 
und gleichzeitig das Risiko eines Eindringens von Krankheiten und Stress für den Baum reduzieren, indem die Wunde schneller geschlossen wird als es natürlicherweise bei Kallusbildung normalerweise der Fall ist.

Resumen. El injerto y el uso de yemas son técnicas hortícolas comunes. Técnicas similares se han utilizado con éxito en el manejo de las heridas de los árboles mediante la aproximación de puente e injerto. El éxito de los injertos de corteza plantea la posibilidad de utilizar injertos de parches de corteza para abarcar heridas de tronco y cortes de poda. Cincuenta árboles de plántulas de cada una de las seis especies nativas y exóticas australianas comúnmente plantadas -Acacia dealbata, Banksia integrifolia, Eucalyptus viminalis, Platanus $\times$ acerifolia, Quercus robur y Pinus radiata-tuvieron tapones circulares de corteza extraídos de su tallo utilizando un barrenador \# 3 (9 $\mathrm{mm}$ de diámetro). Los tapones se levantaron del tallo y luego se volvieron a unir en una de las cuatro rotaciones $(0$, 90, 180 y 270 grados) hasta la orientación cambial original en cada una de las cuatro estaciones.

Aunque no hubo una unión exitosa para Pinus radiata, los datos en las otras cinco especies mostraron que la orientación más exitosa fue en la posición original (0 grados); el pegado exitoso ocurrió en otras orientaciones. La mejor temporada fue la primavera, pero el pegado exitoso ocurrió en otras temporadas. El éxito fue menor cuando se realizó el injerto en invierno.

El uso de injertos de parches de corteza puede proporcionar a los arboristas un método adicional para tratar las grandes heridas causadas por vandalismo y accidentes y sería particularmente útil si un árbol tenía un significado especial, histórico o ambiental para el paisaje. Cubrir la herida con un injerto de parche de corteza puede ocultar la eliminación de una rama, ocultar la cicatriz obvia y al mismo tiempo reducir el riesgo de enfermedad y estrés al árbol mediante el cierre de la herida más rápidamente que la que normalmente se produce debido a la callosidad natural. 